\title{
POLYPLOIDY IN DIOSPYROS VIRGINIANA L. ${ }^{1}$
}

\section{J. T. Baldwin, Jr., and Richard Culp}

Diospyros $L$., the genus of ebony and persimmon, with more than two hundred species widely distributed in the two hemispheres, is chiefly tropical. Geographic occurrence of fossil species of this genus is more extensive, however, than that of those now in existence (see fig. 47 in Berry (1923) for comparison of these areas). Two living species are usually recognized within the limits of the United States: D. virginiana L. and D. texana Scheele. Chromosome numbers for these two species and a cytogeographic analysis of the first of them are given here.

$D$. virginiana, varying from a shrub to a tree with a maximum height of about one hundred thirty feet,

1 Received for publication July 2, 1941.

Papers from the Department of Botany of the University of Michigan, No. 792 . differs considerably in characters of fruit, seed, foliage, etc. Several taxonomic varieties and forms and a number of named horticultural varieties have been established for the species; one variety is sometimes accorded specific rank as $D$. Mosieri Small, of the Florida peninsula. $D$. virginiana is distributed from "New Haven County, Connecticut, and Long Island, New York, through southern Pennsylvania, southern Ohio, southern Indiana and Illinois, to southeastern Iowa, eastern Kansas, central Oklahoma, and southward to De Soto County, Florida, southern Alabama, Mississippi, Louisiana, and Texas to the valley of the Colorado River" (Sargent, 1922).

The authors, through the kindness of various individuals, to whom appreciation is here expressed, assembled single-tree collections of seeds from dif-

TABLE 1. Collections of D. virginiana for which chromosome numbers were determined.

\begin{tabular}{|c|c|c|}
\hline Locality & 2n-number & Collector \\
\hline \multicolumn{3}{|l|}{ Delaware } \\
\hline New Castle County, Newark................ & 90 & F. C. Houghton \\
\hline \multicolumn{3}{|l|}{ Florida } \\
\hline Duval County, Jacksonville.................. & 60 & Olivia Embrey \\
\hline \multicolumn{3}{|l|}{ Georgia } \\
\hline DeKalb County, Emory University............ & 60 & N. H. Giles, Jr. \\
\hline McIntosh County, Fort Barrington $\ldots \ldots \ldots \ldots \ldots \ldots$ & 90 & N. H. Giles, Jr. \\
\hline \multicolumn{3}{|l|}{ Iowa } \\
\hline Linn County, Cedar Rapids.................. & 90 & W. N. Keck \\
\hline \multicolumn{3}{|l|}{ Kansas } \\
\hline 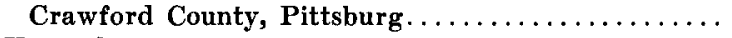 & 90 & J. A. Trent \\
\hline \multicolumn{3}{|l|}{ Kentucky } \\
\hline Madison County, Big Hill................... & 60 & Mary E. Wharton \\
\hline \multicolumn{3}{|l|}{ Louisiana } \\
\hline Natchitoches Parish, Natchitoches............... & 90 & Lauretta E. Fox \\
\hline \multicolumn{3}{|l|}{ Mississippi } \\
\hline Hinds County, Clinton... & 90 & C. L. Deevers \\
\hline \multicolumn{3}{|l|}{ Missouri } \\
\hline Jasper County, Joplin....................... & 90 & J. R. Brooks hire \\
\hline \multicolumn{3}{|l|}{ North Carolina } \\
\hline Wake County, Raleigh...................... & 60 & B. W. Smith \\
\hline \multicolumn{3}{|l|}{ Ohio } \\
\hline 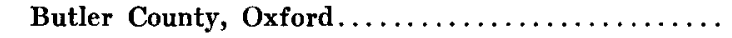 & 90 & Ethel Belk \\
\hline \multicolumn{3}{|l|}{ Pennsylvania } \\
\hline Columbia County, Bloomsburg.............. & 90 & C. A. John \\
\hline \multicolumn{3}{|l|}{ South Carolina } \\
\hline Oconee County, Clemson College.............. & 60 & J. W. Jones \\
\hline \multicolumn{3}{|l|}{ Tennessee: } \\
\hline Davidson County, Nashville................. & 60 & Mrs. J. Hughes Darden \\
\hline Knox County, Knoxville.................... & 60 & J. H. Dean \\
\hline \multicolumn{3}{|l|}{ Texas } \\
\hline Brazos County, College Station. ............... & 90 & C. C. Doak \\
\hline Brazos County, College Station. .............. & 90 & W. S. Flory \\
\hline Williamson County, Georgetown (two collections)... & 90 & G. B. Wolcott \\
\hline \multicolumn{3}{|l|}{ Virginia } \\
\hline Albemarle County, Charlottesville............. & 90 & W.S. Gregory \\
\hline Charlotte County, Keysville.................. & 90 & Mrs. J. T. Baldwin, Sr. \\
\hline James City County, Toano $\ldots \ldots \ldots \ldots \ldots \ldots \ldots$ & 90 & R. W. Menzel \\
\hline Roanoke County, Roanoke.................. & 90 & Bernice M. Speese \\
\hline \multicolumn{3}{|l|}{ West Virginia } \\
\hline Summers County, Hinton.. & 90 & J. E. Miller \\
\hline
\end{tabular}



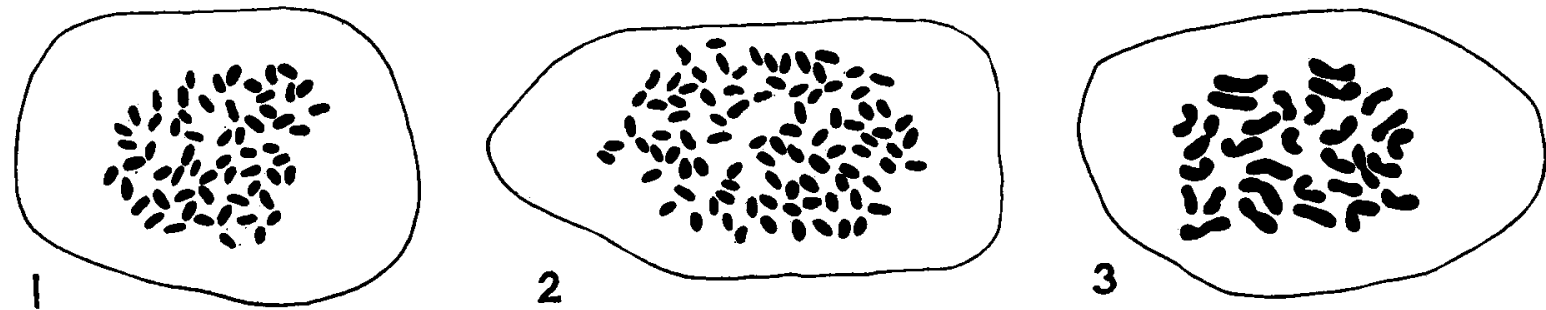

Fig. 1-3. Mitotic metaphase chromosomes of Diospyros.-Fig. 1-2. D. virginiana: $2 n=60$ and 90.-Fig. 3. D. texana: $2 n=30$. Magnification : ca. $1,230 \times$.

ferent parts of the range of this species. Seedlings were grown (and will be maintained) at the University of Michigan Botanical Gardens. Sectioned root-tip preparations (Nawaschin fixative; crystal violet stain) were made from plants of twenty-five collections from twenty-three stations throughout the specific area, and the chromosome numbers determined (table 1).

Two chromosome-number races ${ }^{2}$ were found in $D$. virginiana: $2 n=60$ (fig. 1) and $2 n=90$ (fig. 2). The existence of these races was implied in previous publications: Hague (1911), investigating meiosis of a male tree cultivated in Illinois, observed that "the chromosomes are numerous, 30 at least"; Namikawa,

${ }^{2}$ It is obvious that a chromosome-number race may include more than one genetic race.
Sisa, and Asai (1932) reported a $2 n$-number of 90 for the species.

Relative occurrence of the two races is given on map 1. Although it is not known to what extent man may have been responsible for particular stations (for example, Professor Keck wrote [in a letter] that the collection from Cedar Rapids, Iowa, came from a tree "transplanted from the southeastern corner of the state"), the racial relationship indicated on map 1 may in general be reasonably assumed to be correct: a continuous distribution of the 60-chromosome race in the central and southeastern parts of the specific area; a peripheral distribution (except for barriers) of the 90-chromosome race throughout the rest of the range of the species.

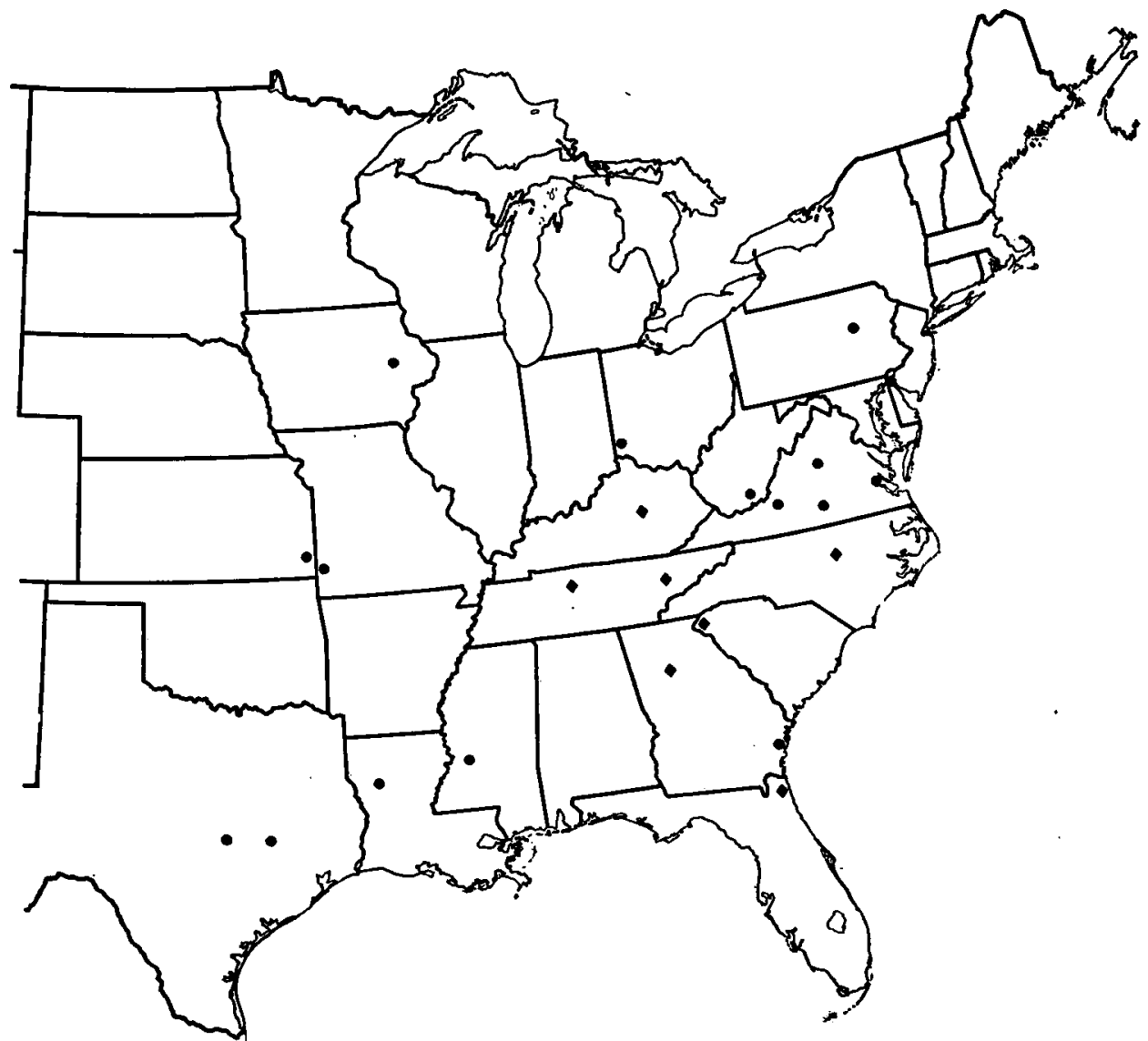

Map 1. Distribution of twenty-three stations of $D$. virginiana: diamonds, $2 n=60$; circles, $2 n=90$. 
To demonstrate the variability of a single character of $D$. virginiana, that of seed shape, there are shown in figure 4 seeds of sixteen collections; both chromosome races are represented. Eventually, upon maturity of the plants here discussed, a detailed comparison of the two races with respect to certain characters will be made. The species is said to be dioe-

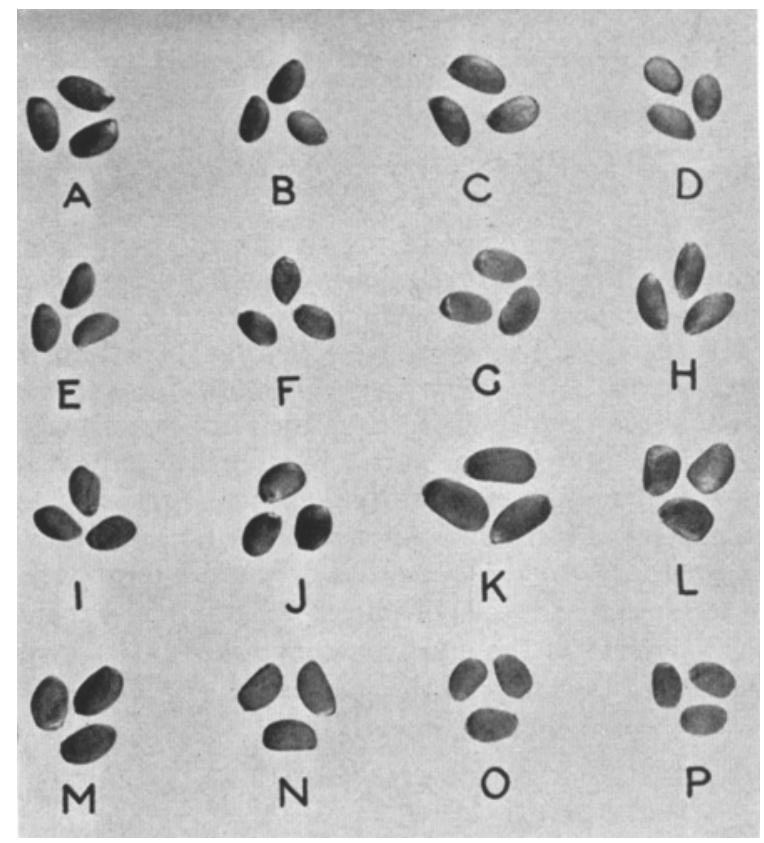

Fig. 4. Seed of Diospyros virginiana from sixteen stations. Collections A-F, $2 n=60 ; G-P, 2 n=90$. A : Clemson College, South Carolina; B: Jacksonville, Florida; C: Knoxville, Tennessee; D: Nashville, Tennessee; E: Big Hill, Kentucky ; F: Raleigh, North Carolina; G: Joplin, Missouri; H: Cedar Rapids, Iowa; I: College Station, Texas; J : Georgetown, Texas; K: Natchitoches, Louisiana; L: Oxford, Ohio; M : Pittsburg, Kansas ; N : Newark, Delaware; $O$ : Hinton, West Virginia; P: Keysville, Virginia. Magnification: $\times 0.38$. Photographed by Dr. Ralph Bennett.

cious; the influence of polyploidy on the expression of sex will be studied.

D. texana is a tree which may attain a height of fifty feet. It occurs variously in Texas and adjacent Mexico. Dr. Gordon B. Wolcott sent us seed of this species from Georgetown, Texas. Seedlings were grown; the chromosomes were counted in aceto-carmine smears of root tips: $2 n=30$ (fig. 3 ). This num- ber, in the light of the others known for Diospyros, gives no basis for the segregation of the species as a monotypic genus, Brayodendron Small.

The basic chromosome number of Diospyros appears to be 15. This is supported by the studies on the two species discussed above and by the following. Namikawa and Higashi (1928) found D. Lotus to have an $n$-number of 15, a $2 n$-number of $30 ; D$. Kaki, in several varieties, an $n$-number of 45 , a $2 n$-number of 90. Yasui (1915) had reported 27 or 28 pairs in $D$. Kaki . The implication is that there are in this species two races which parallel those in $D$. virginiana. Namikawa, Sisa and Asai (1932) recorded a $2 n$-number of 30 for D. discolor.

In consideration of the chromosomal situation in the genus, the two races now known for $D$. virginiana are accordingly to be regarded as tetraploid and hexaploid, respectively. The distribution of the tetraploid indicates that the northern limit of the species during the Pleistocene glacial period was somewhere south of Virginia. Berry (1923), from paleontological evidence, wrote concerning this species that "it is doubtful if its northern limit at any time was farther south than the Potomac River."

D. virginiana is potentially of much economic importance. It serves as a stock upon which oriental persimmons are sometimes grafted, and its fruit, its wood, and certain of its biochemical properties are of varying value. The species thus affords another woody economic plant in which stock-scion relationships with respect to polyploidy may be investigated. For plant-breeding work, whether hybridization be intra- or interspecific, the presence of polyploid races in this species is of considerable significance. In this connection, cytogeographic surveys of other persimmon species should be made. Some of them are variable in such an important character as hardiness: Japanese races of certain species are hardy in "a climate similar to that of New England, and fully as trying to plant life" (Sargent, 1894); some of the characters may be correlated with polyploidy.

\section{SUMMARY}

Diospyros virginiana, a phenotypically variable species, has two chromosome-number races : $2 n=60$ and 90. The distribution of the races is discussed and their horticultural importance suggested.

$D$. texana has a $2 n$-number of 30 .

Department of Botany,
Univensity of Michigan,
An A Arbor, Michigan

\section{LITERATURE CITED}

Berry, E. W. 1923. Tree ancestors. Williams and Wilkins Co., Baltimore.

Hague, Stella M. 1911. A morphological study of Diospyros virginiana. Bot. Gaz. 52: 34-44.

Namikawa, I., and M. Higasmi. 1928. On the number of chromosomes in Diospyros Kaki L. f. and Diospyros Lotus L. Bot. Mag. Tokyo 42: 436-438.
, M. Sisa, and K. Asat. 1932. On the flower types of Diospyros Kaki L. f. Jap. Jour. Bot. 6 : 139-172.

Sargent, C. S. 1894. Forest flora of Japan. Houghton Mifflin Co., Boston and New York.

-1 1922. Manual of the trees of North America. Houghton Mifflin Co., Boston and New York.

YAsur, K. 1915. Studies of Diospyros Kaki. I. Bot. Gaz. $60: 362-373$. 